Терапевтична стоматопогія

УАК 616.348-002-02:616.311.2/.314.1-078

(C). В. Манащук

АВНЗ «Тернопільський державний медичний університет імені І. Я. Горбачевського»

\title{
Зміни в мікробіологічному вмісті пародонтальних та ясенних кишень при захворюваннях пародонта на тлі хронінчих колітів
}

Резюме. У статті наведено результати визначення змін у мікробіологічному вмісті пародонтальних та ясенних кишень у пацієнтів із хронічними колітами. Виявлено дисбіоз кишень, різке зниження частоти висівання оральних стрептококів, лактобактерій, підвищення вмісту стафілококів та виявлення представників заносної фрлори.

Ключові слова: хронічні коліти, мікробіологічний вміст, пародонтальні та ясенні кишені, генералізований пародонтит, катаральний гінгівіт.

\section{Н. В. Манащук}

ГВУЗ «Тернопольский государственный медицинский университет имени И. Я. Горбачевского»

\section{Изменения в микробиологическом содержимом пародонтальных и десневых карманов при заболеваниях пародонта на фоне хронических коллитов}

Резюме. В статье приведены результаты определения изменений в микробиологическом содержимом пародонтальных и десневых карманов у пациентов с хроническими колитами. Определен дисбиоз карманов, резкое снижение частоты высевания оральных стрептококков, лактобактерий, повышение содержания стафилококков и виявление представителей заносной фрлоры.

Ключевые слова: хронические колиты, микробиологическое содержимое, пародонтальные и десневые карманы, генерализованный пародонтит, катаральный гингивит.

\author{
N. V. Manashchuk \\ SHEI «Ternopil State Medical University by I. Ya. Horbachevsky»
}

\section{Changes in the microbiological content of periodontal and gingival pockets in periodontal disease on the background of chronic colitis}

Summary. The results of detecting changes in the microbiology of periodontal and gingival contents of pockets in patients with chronic colitis was given. Revealed dysbiosis pockets, a sharp reduction in the incidence of oral streptococci planting, lactobacilli increased content of staphylococci and detection of representatives flora was revealed.

Key words: chronic colitis, microbiological content, periodontal and gingival pockets, generalized periodontitis, catarrhal gingivitis. 
Вступ. Шлунково-кишковий тракт і тканини пародонта мають тісний анатомічний, нервовий та гуморальний взаємозв'язки [1]. Вони є різними відділами єдиної морфоорункціональної системи, тому порожнина рота тонко реагує на зміни, які в ньому відбуваються $[2,3]$. Супутня патологія травного тракту послаблює захисні сили організму і створює умови для зниження резистентності навколозубних тканин по відношенню до бактерій зубної бляшки й активації пародонтопатогенної мікрофрлори $[4,5]$.

Метою дослідження стало визначення змін у мікробіологічному вмісті пародонтальних та ясенних кишень у пацієнтів із хронічними колітами.

Матеріали і методи. Обстежено 62 хворих із хронічними колітами. 3 них у 46 діагностовано катаральний гінгівіт I, II та III ступенів тяжкості, у 16 - генералізований пародонтит початкового, I та II ступенів тяжкості. Проведені мікробіологічні дослідження показали, що склад мікрофрлори ясенних кишень (при катаральному гінгівіті) та пародонтальних кишень (при генералізованому пародонтиті) у пацієнтів із хронічними колітами носить полімікробний характер і представлений асоціаціями мікроорганізмів (у середньому в одного обстеженого спостерігалось 3-5 видів). Всього висіяно 361 мікроорганізм.

Результати досліджень та їх обговорення. Ступінь загального мікробного обсіменіння ясенних кишень хворих із хронічним катаральним гінгівітом на тлі хронічних колітів становив $(5,62 \pm 2,32) \lg$ КУО/м, коливаючись від $(1,51 \pm 0,62) \lg \mathrm{KУО/мл} \mathrm{(Lactobacillus} \mathrm{spp.)}$ до $(7,78 \pm 1,06)-(7,39 \pm 1,05) \lg \mathrm{KУО/мл} \mathrm{(ана-}$ еробні коки та анаеробні палички відповідно).

Щільність колонізації мікроорганізмами пародонтальних кишень була на порядок вище, ніж у хворих із гінгівітом, і складала $(6,17 \pm 2,56) \lg$ КУО/мл. Як і Аля пацієнтів із катаральним гінгівітом, максимальні показники щільності колонізації кишень були характерні для анаеробних мікроорганізмів, зокрема популяцій Peptostreptococcus spp. $(8,87 \pm 0,45) \lg \mathrm{KУO} / \mathrm{M} \wedge)$ та грамнегативних паличок - $(7,85 \pm 0,83) \lg$ КУО/мл. Мінімальні показники щільності належали Lactobacillus spp. $(1,48 \pm 0,34) \lg$ КУО/мл. Аомінуючими у мікробіоценозах як ясенних, так і пародонтальних кишень були представники аеробних та фа- культативно-анаеробних мікроорганізмів. У мікробній спільноті хворих із гінгівітом вони становили 73,80 \%, з генералізованим пародонтитом - 65,85\%. Із поглибленням запальноАистрофічних процесів кількість строгих анаеробів у складі мікрофлори збільшилася 3 26,30 до $34,15 \%$.

У мікрофлорі пацієнтів із катаральним гінгівітом переважали коки, що становили 49,81 \% усіх висіяних мікроорганізмів. СубАомінантними були палички; їх частка в мікрофлорі була 32,18 \%. Рухомі звивисті фрорми мікроорганізмів займали лише 7,28 \% мікробіоценозу. Аріжджові гриби роду Candida становили більш як 10 \% мікробної спільноти. Аомінантними насамперед були грампозитивні факультативні анаеробні коки, які належали до родів Staphylococcus, Streptococcus, серед яких найвищу частку мали популяції оральних стрептококів (12,64%) та коагулазонегативних стафілококів, до яких належали S. epidermidis, S. haemolyticus, S. saprophyticus, (11,11 \%). Грамнегативні анаеробні коки становили 6,90 \% мікрофлори, й 13,85 \% кокового угруповання. Найменшу частку в мікробіоценозі ясенних кишень займали ентеробактерії, такі, як E. coli, Klebsiella spp. $(2,68$ \%). Анаеробні грамнегативні палички становили 14,33 \% усіх виділених мікроорганізмів. Серед них найвищий відсоток мали популяції превотел (72,09%), а найнижчий - фузобактерій (9,30%). Щільність колонізації ясенних кишень коагулазонегативними стафілококами була $(5,45 \pm 0,85) \lg \mathrm{KУО/мл.}$ Практично такою ж вона була для коагулазопозитивних коків $(5,55 \pm 0,78) \lg$ КУО/мл. Найвища густина була притаманна угрупованню анаеробних паличок, у середньому вона становила $(7,39 \pm 1,48)$ lg КУО/мл. Зокрема, популяції Prevotella spp. колонізували ясенні кишені зі щільністю $(7,62 \pm 0,91) \lg$ КУО/мл, Bacteroides spp. - $(7,02 \pm 1,24) \lg \mathrm{KУO} / \mathrm{M} \Lambda$, Fusobacterium spp. - $(6,31 \pm 1,03) \lg$ КУО/мл. Щільність колонізації досліджуваного топодему представниками Candida spp. була в межах нормальних показників і становила $(3,16 \pm 1,54) \lg$ КУО/мл. У досліджуваній мікрофлорі пацієнтів із генералізованим пародонтитом також переважала кокова група мікроорганізмів і становила 47,00 \% усіх висіяних мікробів. Спектр мікробіоценозу пародонтальних кишень практично однаковий із

ISSN 23 1-9624. Кпінічна стоматопогія. 2014. № 2 
описаним вище: анаеробні грамнегативні палички становили 35,00 \% мікробної спільноти, кандили - 11,00 \%, спірохети - 7,00 \% Найвищу частку в угрупованні коків становили коагулазонегативні коки $(21,28$ \%). Вони разом із превотелами домінували й у мікробній спільноті. Відсоток коків з вираженими патогенними властивостями в угрупованні із поглибленням запальних процесів зріс. Зокрема, кількість оральних, або резидентних ( S. mutans, S. mitis, S. sanguis, S. Salivarius) стрептококів зменшилася у 67 разів, і становила 8,00 \% усіх виділених мікроорганізмів. Частка золотистого стафрілокока серед інших коків зросла в 176 разів і дорівнювала 7,00% мікробної спільноти. Кількість анаеробних коків підвищилася до 19,15 \% усіх висіяних коків і становила 9,00 \% дослілжуваного мікробіоценозу. Частка ентеробактерій у мікробній спільноті пародонтальних кишень більша у 44,67 раза, ніж у мікрофрлорі ясенних кишень, і дорівнювала 6,00% висіяних мікроорганізмів. Густина популяцій коагулазонегативних стафілокококів, оральних стрептококів, ентерококів виявилася однаковою у обох досліджуваних топодемах, проте золотисті стафілококи, піогенні $\beta$-гемолітичні стрептококи, анаеробні коки, анаеробні грамнегативні палички колонізували пародонтальні кишені із щільністю на порядок вищою, ніж ясенні борозни. Рівень колонізації обох топодемів лактобактеріями був на $1-2$ порядки нижчим за норму. Контамінація пародонталь-

\section{Список літератури}

1. Бандрівський Ю. $\Lambda$. Взаємозв'язок захворювань пародонта із соматичною патологією / Ю. $\curlywedge$. Бандрівський, Н. Н. Бандрівська, О.В.Авдєєв // Галицький лікарський вісник. - 2008. - № 4. - С. 95-96.

2. Булкина Н. В. Воспалительные заболевания пародонта у больных хроническим холециститом клинико-инструментальное обследование / Н. В. Булкина, М. А. Осадчук, А. В. Аепилин // Успехи современного естествознания. - 2004. - № 3. - С. 52-53.

3. Булкина Н. В. Патогенетическая взаимосвязь и взаимовлияние воспалительных заболеваний пародонта с патологией сердечно-сосудистой системы и желудочно-кишечного тракта / Н. В. Булкина // Клиническая стоматология. - 2010. - № 2. - С. $28-29$. них кишень кандидами мала патологічний рівень і становила $(5,50 \pm 1,24) \lg$ КУО/мл.

3 найвищою частотою висівали грамнегативні анаеробні палички. У 93,48 \% хворих із катаральним гінгівітом і 100 \% пацієнтів з генералізованим пародонтитом виявлено цю групу мікроорганізмів. Аактобактерії виділені практично у половини обстежених осіб. Частота висівання коагулазонегативних стафілококів була майже однаковою у хворих 3 різною патологією (62,50 - 63,04 \%), проте штами золотистого стафілокока від пацієнтів із пародонтитом висівали у 55 разів частіше. Рідко виділяли коринебактерії, ентерококи. 3 найменшою частотою висівали ентеробактерії, зокрема кишкову паличку й клебсієли, що належали до заносної мікрофлори.

Висновки. Результати досліджень показали, що у хворих із запальними та запально-дистрофічними захворюваннями пародонта (катаральний гінгівіт та генералізований пародонтит) на тлі хронічних колітів домінували фракультативні аероби, проте кількість облігатних анаеробів зростала із поглибленням патологічних процесів у пародонті. У всіх хворих виявлено дисбіоз кишень, так як було відмічено різке зниження частоти висівання оральних стрептококів, лактобактерій, підвищення вмісту стафілококів та виявлення представників заносної флори (клебсієл та кишкових паличок), щільність колонізації досліджуваних топодемів популяціями стабілізуючої фрлори менша за показники норми.

4. Цимбалистов А. В. Патофизиологические аспекты развития сочетанной патологии полости рта и желуАочно-кишечного тракта / А. В. Цимбалистов, Н. С. Робакидзе // Стоматология для всех. - 2005. № 1. - С. $28-34$.

5. Роль патологии желудочно-кишечного тракта в патогенезе генерализованного пародонтита и пути его коррекции на этапах комплексного лечения / И. В. Чайковская, Е. В. Комаровская, Н. В. Мозговая [и др.] // Питання експериментальної та клінічної медицини : збірник статей. - Аонецк, 2011. - Вип. 15, T. 1 - C. $324-330$. 